\title{
Looking into In-Service Training for Teachers in the Philippines: Are They Gearing towards Education 4.0?
}

\author{
Fernan Peniero Tupas ${ }^{1,2, *}$, Rosario P. Noderama ${ }^{3}$ \\ ${ }^{1}$ Department of Biology, School of Arts and Science, Northern Iloilo Polytechnic State College, Philippines \\ ${ }^{2}$ International Research Fellow, Japan Society for the Promotion of Science, Laboratory of Biotechnology and Bioengineering, \\ Hokkaido University of Education, Japan \\ ${ }^{3}$ Department of Science, College of Criminal Justice Education, Northern Iloilo Polytechnic State College, Philippines
}

Received June 23, 2020; Revised July 28, 2020; Accepted August 25, 2020

\section{Cite This Paper in the following Citation Styles}

(a): [1] Fernan Peniero Tupas, Rosario P. Noderama, "Looking into In-Service Training for Teachers in the Philippines: Are They Gearing towards Education 4.0?," Universal Journal of Educational Research, Vol. 8, No. 10, pp. 4651-4660, 2020. DOI: 10.13189/ujer.2020.081034.

(b): Fernan Peniero Tupas, Rosario P. Noderama (2020). Looking into In-Service Training for Teachers in the Philippines: Are They Gearing towards Education 4.0?. Universal Journal of Educational Research, 8(10), 4651-4660. DOI: 10.13189/ujer.2020.081034.

Copyright $\bigcirc 2020$ by authors, all rights reserved. Authors agree that this article remains permanently open access under the terms of the Creative Commons Attribution License 4.0 International License

\begin{abstract}
Professional development, such as In-Service Training for Teachers (INSET) of the Department of Education (DepEd), is one of the tools to help improve teaching-learning. The current trend is Industrial Revolution 4.0, and the education system is to gear toward Education 4.0. This qualitative research used automated micro-targeting, interview, and document analysis. This study aims to identify the themes and integration of Education 4.0 in the conduct of INSET during School Year (SY) 2019-2020. The results exposed INSET this academic year is focused on teachers' and students' development as a whole in both summer and semestral break training. Almost all the topics are content-based, and no hands-on activities are facilitated except for action research making. None of the themes or topics selected for Education 4.0. In Category A, the highest answers were of the whole informants revealed $77.78 \%$ for "INFORMATIVE"; in Category B, the highest was $75.00 \%$ for "USELESS"; and in Category C,52\% for "NOT AWARE." Luzon showed a positive response in the implementation of INSET, but in the Visayas, the majority are not satisfied with how the training was conducted. The education system of the Philippines will continue to suffer if there is no fixed standard for INSET and reflected in numerous local and international assessments. Evaluation is the key to identify the advantages and disadvantages of INSET. Furthermore, to increase interest and participation among teachers,
\end{abstract}

hands-on activities and current trends are suggested for the themes. School heads adopt the Lesson Study approach in implementing INSET activities.

Keywords Professional Development, Department of Education, Basic Education, Teachers, Topics, Themes

\section{Introduction}

Completing four years in college doesn't guarantee that you have learned everything to become competent professionals. For instance, in teaching, all teachers are required to attend various professional developments such as graduate studies and seminars, training, workshops, and even conferences - additional training necessary to become competent and efficient teachers. However, there is no specific formula on how to become quality teachers, but the performances of students in different assessments are the gauge by the department. Thus, Continuing Professional Development (CPD) is a mandatory requirement of the Professional Regulation Commission (PRC) for license renewal started in 2017. The primary purpose of the CPD is to upgrade the professional practices by international standards [1]. The low quality of education in the Philippines is the lack of competent teachers [2]. Professional enhancement is essential to 
answer gaps in education systems. Various local and international organizations prepared the training to accommodate professionals. However, not all teachers have the opportunity to attend training, workshop, seminars, and conference due to a lack of financial and administrative supports. For many years, many teachers clamor that the same faculty sent to attend these activities.

In the Department of Education (DepEd), twice a year of professional development activity called In-Service Training for Teachers or INSET are planned by the department and organized per district. Every district in the entire archipelago held this training every May and October of each school year. This five days annual and semestral break training [3] approved by the DepEd, talks about current trends and issues in the Philippine education system. They invited experts and practitioners to help them bridge the gap in the perennial problem in the primary education curriculum. INSET is to orient teachers about national and regional programs tailored to the needs of the whole system. Also, this is to improve the professional growth of teaching force abreast of current trends and knowledge [4]. The specified issues on professional development, such as allowing teachers with a low level of quality to attend training, support from the administrations, and budget not utilized well [5].

There is a call from primary education practitioners to recognize INSET as one of the professional development providers. But, the assurance of quality training during INSET must be required and assessed.

In-service education for teachers is critical because it can help teachers' professional growth and development. Furthermore, teachers to become productive and efficient about various pedagogy and modern trends, they must be encouraged to attend the professional event [6]. Professional development, like in-service training, is an essential tool for successful teaching and learning. Moreover, the traditional approach in education has less impact on learners' performance, but repetitive intervention like training teachers can affect educational techniques [7]. These methods used effectively lead to improving learning outcomes [8]. Hence, the proper facilitation and exact designs of INSET based on the current needs of the school in the locality is required. The Philippines is facing various backlash, such as instructional materials, qualified teachers, infrastructures, etc. In the proposal of every school, monitoring and assessment needed after the INSET is implemented.

Also, the Inclusion Caravan for regular teachers handling disabled learners suggested training programs to enhance knowledge and understanding to accommodate learners with disabilities. The program showed that in every aspect of the education system, in-service training for teachers is very vital [9]. Some of the topics suggested by DepEd classroom assessment about the new curriculum, the K12 Basic Education Program [10]. Some experts from different Division Offices in the country selected instructional materials preparation as one of the essential professional growth of the teachers [11] [12].

The primary purpose of this study was to determine the integration of Education 4.0 in the conduct of INSET in the Philippines. Also, this study aims to document the themes of INSET in the country. Furthermore, this is also to recognize the insights of basic education teachers about the conduct of INSET and Education 4.0.

\section{Background}

The K-12 was first introduced during the academic year 2012-2013 under Republic Act 1033 [13]. The Enhanced Basic Education 2013 was materialized because, for the past decades, students' performances were always below the standards. The basic education is now divided into 1-year compulsory kindergarten, six years in elementary, four years in junior high school (JHS), and two years in senior high school (SHS)compared to the previous ten years [14]. The salient points of the new curriculum are the establishment of early childhood education and spiral approaches [15]. Also, the additional two years for senior high school as a position to international norms [14], using the mother-based tongue as medium of instruction, and the holistic style of development are additional unique features of the new program. Also, one of the promises of the new curriculum is labor opportunity [16]. But the critics disputed about the readiness of the entire archipelago to grasp the latest development. Also, the additional two years required other expenses for the parents [17]. To solve these problems and issues about the new curriculum, listening to all voices is the solution [18]. However, the new curriculum is an advantage to those who want to go for farther studies and work abroad [14]. For instance, nursing graduates in the Philippines working abroad given a nursing aid position or engineers are only technicians because of the lacking two years in the basic education program. All graduates in the master's degree program cannot proceed to a doctorate because they only have ten years in elementary.

In the science curriculum, teachers must work harder about integrating science in various disciplines. Also, the spiral approach and the use of indigenous materials in science teaching is critical in the K12 [13]. Thus, professional development is needed to achieve this goal. Furthermore, teachers play a big part in delivering quality education; as a result, training is essential. The national government should allocate an additional assistant to DepEd for professional growth opportunities[18]. Specifically, in the science education curriculum, perennial problems like science textbooks, laboratory facilities, and qualified teachers [15] pieces of training are required. To improve the quality of education in the country and to increase the students' performance, teachers must be valid and efficient. Thus, improving the 
quality of teaching is the answer [19].

In the history of the Industrial Revolution, stages like physical labor to mass industrial production involved in information technology to the digital revolution. The movement into the smart industry and manufacturing goal is called the Industrial Revolution (IR) 4.0 [20]. The concept of IR 4.0 is about global connectivity, advanced technology, and a new form of media; hence, the curriculum is associated with these up-to-date innovations. The IR 4.0 was first introduced in 2011 [21]. Countries in ASEAN are focusing on automation, data exchanges, cloud computing, cyber-physical systems, robots, Big Data, Artificial Intelligence (AI), Internet of Things (IoT), and semi-autonomous industrial techniques as industrial transformations. Also, IR is composed of six building blocks. These are (1) technical success skills; (2) industrial equipment and technology; (3) smart sensors and smart devices; (4) control systems; (5) connectivity and networking; and (6) inform-actionable data [20].

Furthermore, the Philippines is gearing towards the Industrial Revolution or IR 4.0. The education system in the country adopted Education 4.0. Education plays an integral part in integrating IR 4.0 in the curriculum to produce career-ready citizens [20]. The new trend requires educators to prepare learners in a wide array of skills and knowledge as well as practical experiences (Alvior 2014). But is the department already embedded in this new trend in the curriculum? The latest trends were answered through topics selected during the INSET. IR 4.0 was introduced in 2011 [21].

Education 4.0 is an image of the era of Industry 4.0. Education 4.0 is a period in which education paradigms, approaches, and technologies have changed. Thus, major technology trends are the current educational system. Education experts and practitioners around the world changed educational standards and teaching approaches [22]. Schools are encouraged by non-traditional methods to use technological base tools in teaching [23]. Educators today are forced to cope with technological advancement. They pushed to reconsider modifications of the curriculum to prepare students for the future [24]. DepEd officials are encouraged to start incorporating Education 4.0 in INSET.

\section{Methods}

\subsection{Research Design}

This study is qualitative research. Specifically, the research design is a case study that typically applied in social, and life sciences are about studying a person or a group of individuals or entities that aims to extract themes or concepts. Furthermore, a rigorous inquiry by the researcher examines different collected variables [25]. A Case study was utilized to intensively analyze the selected elementary and secondary eachers in the Philippines, particularly in their participation in the INSET 2019-2020.

\subsection{Methods of Research}

This study employed methods such as automated micro-targeting, interviews, and document analysis. Automated micro-targeting, or usually called microtargeting, is a selection process of a target audience using messages online [26]. In the advent of social media like Facebook, it is timely and relevant to use in this endeavor. The distance of various selected informants, microtargeting was helpful in this study.

The interview is about describing the meaning of the main themes as well as in-depth information or factual around ideas [27], [28]; in-depth interviews were applied in this study to gather information and insights from primary education teachers about how their respective stations conduct INSET.

All the documents such as programs, proposals, etc. were collected; thus, document analysis was used. Hence, document analysis is an organized approach to evaluate or review all forms of materials and interpret these documents to produce information based on the themes and concepts.

\subsection{Informants}

Table 1 summarizes the number of science teacher participants of the study

The informants of this study were from the Facebook friend list of the researcher. All basic education teachers from the DepEd were given an informal invitation through a messenger that they selected as a participant of this study. They were given a week to decide whether to accept or reject the request.

Table 1. Summary of the informants of the study

\begin{tabular}{|c|c|c|c|}
\hline $\begin{array}{c}\text { Part of the } \\
\text { Country }\end{array}$ & Elementary & $\begin{array}{c}\text { Junior High } \\
\text { School }\end{array}$ & $\begin{array}{c}\text { Senior High } \\
\text { School }\end{array}$ \\
\hline Luzon & 12 & 12 & 12 \\
\hline Visayas & 8 & 8 & 8 \\
\hline Mindanao & 4 & 4 & 4 \\
\hline Total & 24 & 24 & 24 \\
\hline
\end{tabular}

\subsection{Instruments}

The instrument utilized in this study was a ready-made-questionnaire which acts as a guide during the interview and discussion. These five items open-ended questions allow the informants to respond independently. The conversation was tape-recorded to capture all the responses of the informants.

Also, the researchers created a guide to help them as to what specific data were needed to be collected-the activity proposals, permits, programs, etc.were utilized as an instrument in this study. 
Table 2 shows the checklist on how to evaluate INSET.

Table 2. Checklist for INSET and Education 4.0

\begin{tabular}{|c|c|}
\hline & Responses \\
\hline Category $\boldsymbol{A}$ & \\
\hline Informative & \\
\hline Relevant & \\
\hline Timely & \\
\hline Interesting & \\
\hline Category $\boldsymbol{B}$ & \\
\hline Irrelevant & \\
\hline Tiresome & \\
\hline Useless & \\
\hline Waste of Resources & \\
\hline Category $\boldsymbol{C}$ & \\
\hline Aware & \\
\hline Not Aware & \\
\hline Not Interesting & \\
\hline No Reaction & \\
\hline
\end{tabular}

Furthermore, a checklist was used as an instrument to determine the knowledge of informants about Education 4.0: their interest in the themes or topics they have selected during the INSET included understanding the activity further. The checklists were divided into three categories; Category A is about the positive aspects, Category B about negative comments, and Category $\mathrm{C}$ is about Education 4.0. The items in each group were identified by non-science teachers who refuse to become informants. The top 4 of their responses were taken as bases to evaluate INSET and Education 4.0. All the instruments were assessed by experts.

The informants checked the boxes of their answers on the three categories. They can check all items based on their experiences.

\subsection{Analysis}

The replies from the microtargeting and interviews were transcribed, coded, theme, and triangulated. The observations and documents were also analyzed-the responses for Category A and B counted, and the percentage of the checklist Category $\mathrm{C}$ taken. In general, the rate of each item in Category A and B was computed.

\subsection{Ethical Consideration}

A codename was designated to hide their identity. All the data collected were destroyed after the completion of the study. But before the engagement, the study permit was distributed for the approval of the school heads.

\section{Results and Discussion}

\subsection{INSET in the Philippines}

Table 3 shows the different items during the INSET 2019-2020 for teachers.

Table 3. Topics on Teachers during INSET in the Philippines in Academic AY 2019-2020

\begin{tabular}{|c|c|}
\hline Topics & No. of Responses \\
\hline Gender and Development (GAD) & 60 \\
\hline Intellectual Property Rights & 55 \\
\hline Coping with Stress and Social Issues & 53 \\
\hline $\begin{array}{c}\text { Result-based Performance Management } \\
\text { System (RPMS) }\end{array}$ & 52 \\
\hline Updates & 49 \\
\hline $\begin{array}{c}\text { School-Based Disaster Risk Reduction and } \\
\text { Management }\end{array}$ & 45 \\
\hline Basic Life Support & 42 \\
\hline $\begin{array}{c}\text { Information and Communication } \\
\text { Technology (ICT) }\end{array}$ & 40 \\
\hline Right of Children & 40 \\
\hline Philippines Cybercrime Law & 35 \\
\hline Mental Health & 33 \\
\hline Personality Development & 30 \\
\hline Teacher's Code of Ethics & 29 \\
\hline GSIS: Benefits and Privileges & 28 \\
\hline
\end{tabular}

These topics selected for AY 2019-2020 INSET based on the suggestions coming from DepEd, were adopted by the Regional and Division Offices and recommended by the experts to the district. School administration deliberated on all the topics and picked only the very important that are needed for school improvement and increase performances of the learners. Each school will submit proposals in April for Summer and in September for Mid-year to the division office for approval.

School heads designated teachers or groups of experts to evaluate the local needs. However, no consultation among teachers about the chosen topics. INSET in the Philippines focused on teachers' and students' development. The department based this on everyday issues and problems that arise during the recent academic year.

The operational leadership skills of school heads to manage proactive teachers are the key to school performances. Hence, for teachers committed in all aspects of pedagogy, principals and the administrations need to exercise active headship skills [29]. Training teachers is the tool to make them equipped with the tools required to become competent and efficient Filipino educators [18]. Also, habits and experiences are common factors that disturb teaching performances. Furthermore, they stressed that all principals and school heads must invest in training and development to bring the best among 
teachers [30].

The tomost topic is Gender and Development, or GAD. In the principles of gender equality, gender equity, gender sensitivity, non-discrimination, and being humane in line with Gender and Development (GAD) are stipulated in the 1987 constitution. Deped creates Gender-Responsive Basic Education Policy to guarantee access to quality education for all [31]. The Gender and Development or GAD is required to be conducted by schools as part of professional development [32]. Thus, this is often part of the INSET to save time and effort.

This next highest response is Intellectual Property Rights. DepEd assured all innovations of the members of the department will be protected; thus, the Memorandum of Agreement (MOA) between the World Intellectual Property Organization (WIPO) and DepEd inked to help all the primary institutions in the country. With this, various training was organized to equip teachers with intellectual property matters. But because not all were allowed to attend, local preparation was held [33].

Furthermore, another topic is coping with stress and social issues. Teaching is a very stressful profession; aside from educating learners, they still do paper works, extra-curricular activities, and additional office functions. They are prone to stress that causes various illnesses. Teachers must possess thinking, emotions, and behavior that are positive to boost their potentials in all aspects [34].

Also, Results-based Performance Management System or RPMS is one of the top topics in INSET 2019-2020. The RPMS was created by the department to help all basic education and public institutions management in the entire archipelago be implemented well and effective [35]. Thus, all schools are encouraged to train faculty and staff about RPMs.

Updates are about the current trends and issues in basic education. With all the natural events that occurred in the past, teachers must be well-equipped of School-based Disaster Risk Reduction and Management and Basic Life Support. Also, in the advent of technology, they must be knowledgeable about ICT.

In the past, there were many issues about corporal punishments. In recent years, the Child Protection policy was implemented by the national government. As instructed by DepEd, all teachers must be educated to stop the problems related to child punishment and bullying. Today, social media is the fashion. To give insights about protecting teachers and other stakeholders, this becomes one of the trends in INSET. Staying 8 hours per day for five days a week, with all the pressures in teaching, is mentally draining. Thus, mental health is also a concern-Doctors who are experts in this field are invited to help teachers. But education is not about work; looking good is also a strategy - teachers were trained to always look presentable in front of their classes.

Teacher's Code of Ethics of the Board of Professional Teachers was taken from Resolution 435, series of 1997, states that all license teachers should possess dignity and reputation with high moral, technical, and professional competence [37]. For the past years, there were many reported problems of teachers in dealing with students, financial hard-ups, and many more. The Philippine Regulation Commission and DepEd central office informed teachers about their duties and responsibilities. Then, this call becomes one of the critical topics in INSET.

The importance of training for future teachers about stressful situations during actual teaching is required. The ability to regulate oneself from the external and internal interventions of one's psycho-emotional well-being in education is also essential to learn by future teachers [38].

Table 4 summarizes the common theme of INSET focused on students' welfare.

Table 4. The themes for Science Education Curriculum for INSET during Academic Year (AY) 2019-2020

\begin{tabular}{|c|c|}
\hline Topic & $\begin{array}{c}\text { No. of } \\
\text { Responses }\end{array}$ \\
\hline Pedagogical Retooling in Science & 60 \\
\hline Critical Content in Junior High School & 59 \\
\hline Problem-Based & 58 \\
\hline Language Strategies in Teaching Science & 57 \\
\hline Development of Interactive Lessons & 55 \\
\hline $21^{\text {st }}$ Century Skills, Teaching and Innovations & 54 \\
\hline Action Research & 50 \\
\hline Contextualization, Localization & 49 \\
\hline Differentiated Instruction & 45 \\
\hline Sponge Learning & 40 \\
\hline Learning Process & 35 \\
\hline Different Approaches in Enhancing Teaching and & 34 \\
\hline Demonstration Teaching and Critiquing & 30 \\
\hline
\end{tabular}

All the topics selected are essential in the science curriculum. For the past seven years after the implementation of $\mathrm{K} 12$, teachers are still learning how to implement the new curriculum effectively. Specifically, that majority of old teachers are hesitant to learn, and hiring new teachers need to be upgraded. Selecting themes for INSET must be relevant to the needs of the learners as a whole. Also, the current trends in education must be considered integrating into the INSET. Experts are invited to talk about specific topics but need to screen appropriately. For instance, the practical implementations of the spiral program in science are to develop in-service training sufficiency to improve the performance of teacher's content, pedagogy, and assessment [38]. To become effective teachers, the range of strategies is essential. But none has the interest to include a spiral approach and how should it be implemented effectively inside the classroom. There are still teachers in the field, teaching other subject areas, and should be given importance during the INSET. Furthermore, the use of localization and contextualization is emphasized because resources are limited [39]. 
To succeed, the objective in science education, critical thinking, and innovative approach is essential. Results of their study exposed that creative innovations in science teaching make learning fun and exciting. Pedagogical Retooling in Science aims to improve knowledge and skills in executing the science curriculum [40]. Also, this is to mentor through professional development the teaching and learning outcomes [41].

Critical content in junior high school (JHS) is essential. The spiral approach in Science in JHS becomes more complicated. Thus, teachers are required to implement effectively - training is the key. Teachers must identify precisely and critically the content during a lesson to develop progression among learners [42].

Japan and other neighboring countries which advocate the Lesson Study (LS), and the Philippines, which also implemented the same approach during the Basic Education Curriculum (BEC). The lack of interest in sustaining the operation of LS should be given importance by DepEd because many studies showed LS has a significant effect on the teaching-learning process. LS has a contributing factor in improving the role of teachers and a better understanding of how to become a competent and efficient moderator of learning [43].

Figure 1 represents the responses of the informants in Category A. Responses of the whole informants revealed $77.78 \%$ for "INFORMATIVE," $70.83 \%$ for "TIMELY," $55.56 \%$ for "INTERESTING," and $48.61 \%$ for "RELEVANT." Luzon informants showed positive responses to the implementation of the INSET, followed by Mindanao, and lastly, the Visayas. DepEd Central Office is in Luzon; thus, all teachers are always privileged to get the first-hand information and implementation of the current trends. In general, schools in Visayas and Mindanao, the themes are still new to them; thus, new knowledge is learned but not adequately employed in teaching.

This activity is frequently inviting experts to talk about current trends. But one familiar problem teachers faced after the training is the sustainability of the new knowledge. Aside from this training, district, division, regional and national also organized training, conferences, and workshops - many of these activities are executed during school hours. Thus, the lesson for the entire academic year cannot be accomplished, and results in the National Achievement Test (NAT) are affected.

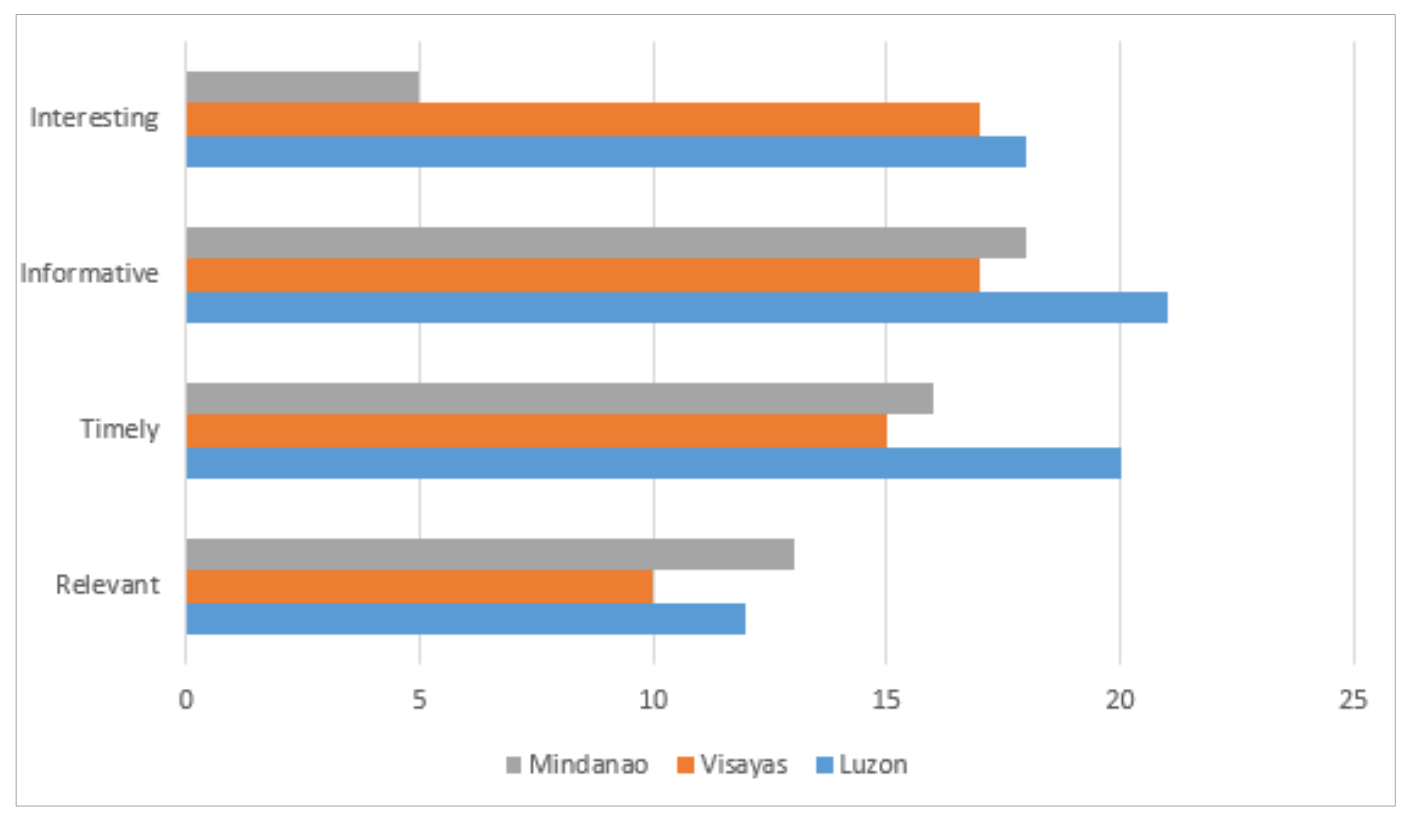

Figure 1. Responses of informants in the Category A. 
Figure 2 shows the responses of the teachers in Category B, and shows $75.00 \%$ for "USELESS," $68.06 \%$ for "TIRESOME," $61.11 \%$ for "IRRELEVANT," and $59.12 \%$; for "WASTE OF TIME." Furthermore, the informants from the Visayas were not satisfied with INSET compared to Mindanao and Luzon. The results in NAT for the past years in the Visayas are alarming.

The topics during INSET are loaded. Teachers stayed for 8 hours for one week listening to all these problems and issues are not sufficient. Almost half of these teachers attending the training always have negative comments about the activity. The national government should conduct assessment and evaluation for the implementation of the INSET in the entire country. The review is to solicit positive comments and best practices among schools in the archipelago. There are no innovative approaches in INSET for the past years.

All the issues in INSET are always content-based, with no hand-on activities except for action research, instructional materials preparation, and demonstration teaching. Still, nobody implements in the actual classroom setting. The problem is sustainability—also, no evaluations among the heads.

According to informant 2;

"Our head invited speaker on action research, but the guest only communicated about the meaning of action research and its part. She cannot show any outputs of her own. I don't think she is an expert."

All of them agreed; the government is just wasting money and efforts in the conduct of INSET. They should create

\subsection{Gearing towards Education 4.0}

Table 5 shows the responses about the integration of Education 4.0 in the INSET.

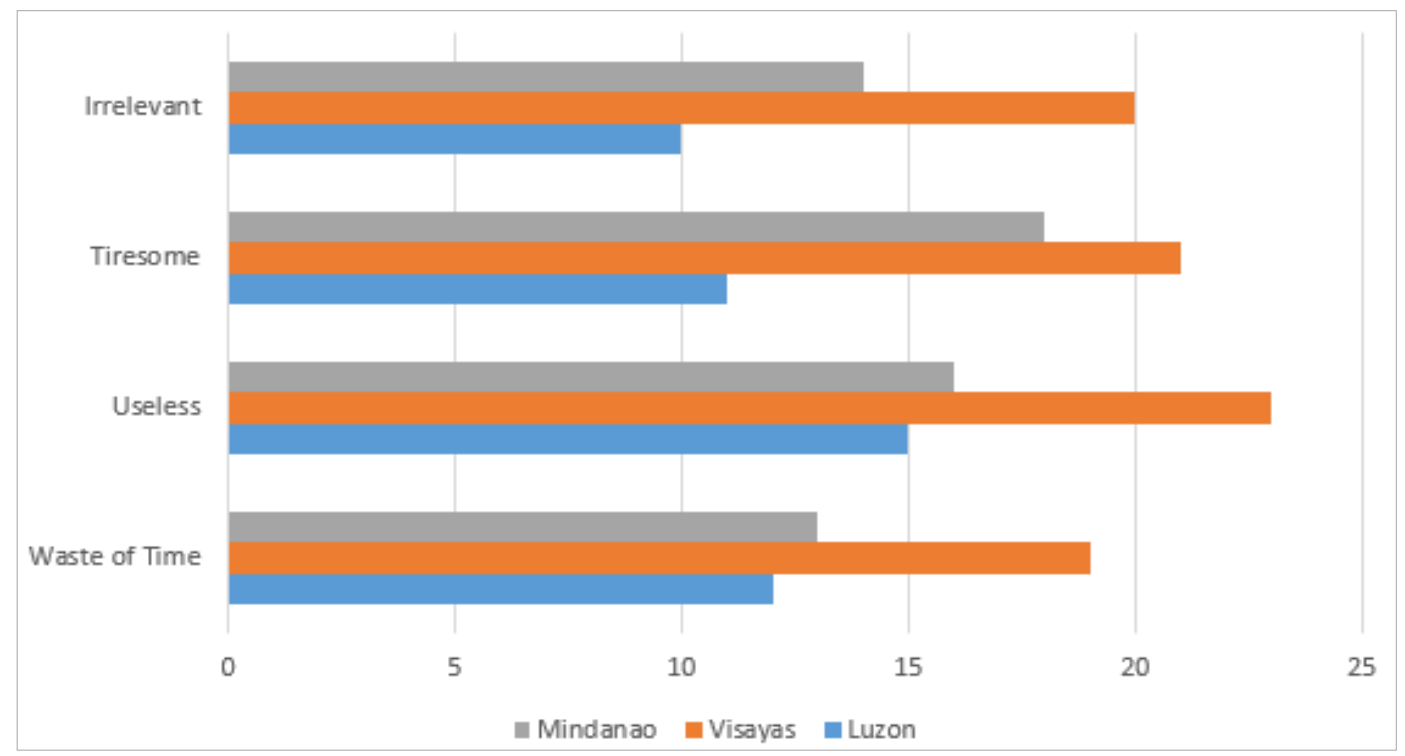

Figure 2.Responses of informants in Category B.

Table 5. Responses of the Informants about Education 4.0 in INSET

\begin{tabular}{|c|c|}
\hline Informant \# & Responses \\
\hline \multirow{2}{*}{$\begin{array}{c}1,2,14,15,18,21,23,28,29,30,31,33,34,37,39,41, \\
43,45,46,50,52,57,61,62,65,66\end{array}$} & $\begin{array}{l}\text { "I have no idea about Education 4.0." } \\
\text { "I have attended all the INSET for almost years now but haven't heard } \\
\text { about Education 4.0." }\end{array}$ \\
\hline & "All the topics in INSET are content-based, and it's already boring." \\
\hline \multirow[b]{2}{*}{$\begin{array}{c}2,3,4,9,10,11,13,17,20,22,24,31,35,36,42,44 \\
45,46,51,55,56,59,63,67,68\end{array}$} & $\begin{array}{l}\text { "I have read Education 4.0, but I didn't see that integrated into our INSET." } \\
\text { "I know that it's all about the Industrial Revolution 4.0, but I think it will be } \\
\text { hard for us because we don't have any facilities." }\end{array}$ \\
\hline & $\begin{array}{l}\text { "This Education } 4.0 \text { is fascinating, but with the current situation of our } \\
\text { school, we are not ready." } \\
\text { "We don't even have a computer, and we are still using the traditional } \\
\text { approach." }\end{array}$ \\
\hline \multirow[t]{2}{*}{ All } & $\begin{array}{l}\text { "It will take time to integrate this in the INSET if we do; new trends are } \\
\text { coming out." } \\
\text { "The culture in the department is different; we have to tap young minds to } \\
\text { lead us." } \\
\text { "I saw young administrators; they have different visions compared to old } \\
\text { ones." }\end{array}$ \\
\hline & $\begin{array}{l}\text { "I am retiring; these technologies in teaching makes me sick." } \\
\text { "But during my younger years, I am very active." } \\
\text { "But I saw something different in the system that affect our performances." }\end{array}$ \\
\hline
\end{tabular}


It will be difficult for the department to implement Education 4.0 without the facilities. The K12was implemented in 2012, but until now, the scarcity of teaching materials is still the problem. The basic education is not ready for Education 4.0. This new trend shapes and changes the landscape of the education system. For society to be prosperous, people need to learn new things in all aspects [44].

Figure 3 represents the knowledge of science teachers in Category $\mathrm{C}$; the responses revealed $52 \%$ for "NOT AWARE," $22 \%$ for "AWARE," $14 \%$ "NOT INTERESTING," and 12\% "NO REACTION." This figure showed the majority of science teachers unaware of Education 4.0. The age and interest affect the responses of the informants. Older science teachers unmindful and no interest in Education 4.0; many of them are still using the paper and pencil strategy. However, younger teachers are mindful of the current trend in the education system, and they are willing to learn. The lack of facilities to cope with the trends is always a perennial problem in the Philippine education system.

\section{Conclusions}

Professional development such as In-Service Training for Teachers (INSET) of the Department of Education is one of the tools to help improve teaching and learning approaches. However, the fast-changing technological advancements like the current trend Industrial Revolution 4.0 and the education system in the country suggested to gear towards Education 4.0. This study aims to identify topics of INSET in School Year 2019-2020 towards Education 4.0. INSET is organized and facilitated during summer and semestral break. The INSET for SY 2019-2020 focused on teachers' personal and professional development as well as to increase students' interest in studying and performances in various national and international assessments. Almost all the items are content-based, and no hands-on activities were included except for action research making. The teachers were asked to create a research proposal but not assessed and implemented. They also tried to develop innovations through Instructional Materials Preparation, but due to limited time and additional functions, creative outputs were not utilized effectively. But many of the topics are irrelevant to improving teachers' effectiveness and efficiency - none of the issues gears towards Education 4.0. Teachers have limited knowledge about this new trend, and many of them are not interested because they are still facing various problems such as instructional materials, classroom facilities, school building, etc. in the implementation of the K12 Basic Education Program. They are also complaining about how the department handles the new curriculum. They also suggested that all higher officials conduct researches about the status of the K12 curriculum to answer the clamor of various stakeholders. The education system of the Philippines will continue to suffer if there is no fixed curriculum standard and will affect the performance of learners in numerous local and international assessments.

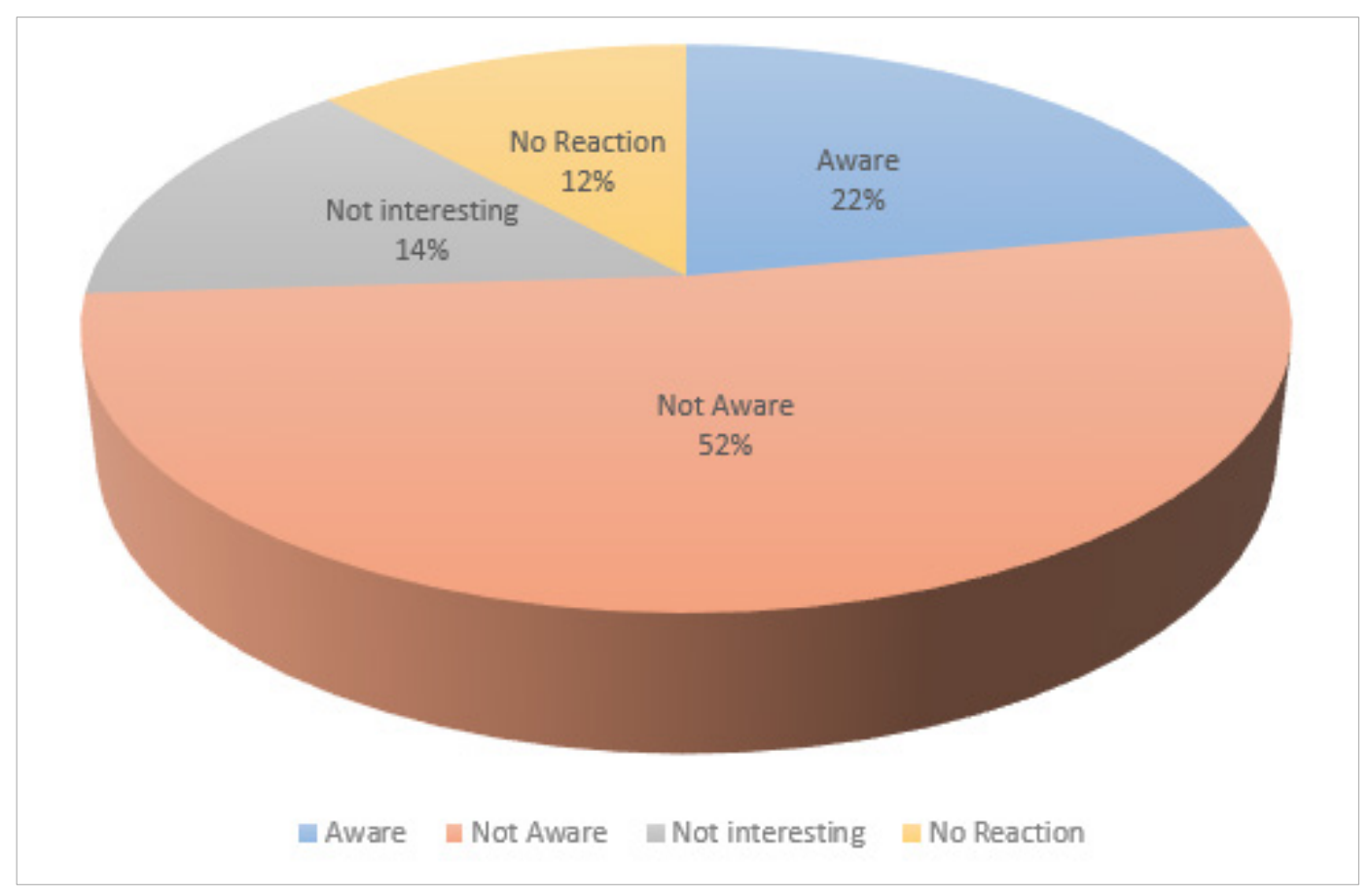

Figure 3. Knowledge of the informants about Education 4.0. 
But teachers are still interested in attending INSET every year due to knowledge learned during the training. Even some are irrelevant but always informative. The lack of awareness about Education 4.0, INSET, plays a vital role in educating science teachers about the current trends.

School administrators should select one expert in the school to spearhead all the INSET activity. This focal person should encourage researching to choose the basic needs of the institution like how to improve students' performances in all given assessments by the department and also the international organization. Train teachers on how to deliver pedagogy effectively, the use of local resources in teaching, improve the quality of education through research.

\section{Acknowledgments}

The researchers extended their heartfelt gratitude to all science teachers taking the time to answer all the queries.

\section{REFERENCES}

[1] Republic Act No. 10912. "An Act Mandating and Strengthening the Continuing Professional Development Program for All Regulated Professions, Creating The Continuing Professional Development Council, and Appropriating Funds Therefor, And for Other Related Purposes." Manila, Philippines: Professional Regulation Commission, 2016, pp 1-6.

[2] Alvior, M. G. "Research of the Professional Development Model for Teachers."

https://simplyeducate.me/2014/12/17/a-research-on-the-pro fessional-development-model-for-teachers/. (accessed May 12, 2020).

[3] DepEd Order No. 007 s. 2019. "School Calendar for School Year 2019-2020.” Pasig City, Philippines: Department of Education, pp. 1-11.

[4] Facturan, M. B. "The Importance of In-service Training to Teachers in our School System. http://www.centralluzon.com/content/view/202/9/. (accessed April 23, 2020).

[5] Gonong, G. O. "Addressing teacher professional development issues: supporting teachers' quality."https://www.deped.gov.ph/wp-content/uploads/2 018/07/EducSummitAddressingTeacherProfessionalDeve lopmentIssues.Nov2_.pdf. (accessed May 2, 2020).

[6] Osamwonyi, E. F. "In-Service Education of Teachers: Overview, Problems, and the Way Forward.: Journal of Education and Practices, vol. 7, no. 26, pp. 83-87, 2016.

[7] Quint, J. "Professional Development Teachers." https://www.mdrc.org/publication/professional-developm ent-teachers. (accessed May 24, 2020).

[8] Bluestone, J., Johnson, P., Fullertone, J., Curr, C., Alderman, J., Tempo, J. B. "Effective In-service Training
Design and Delivery: Evidence from an Integrative Literature Review." Human Resources Health, vol. 11, no. 51, 2013. DOI:10.1186/1478-4491-11-51.

[9] Villamero, R. "Teacher Training in Inclusive Education: A Reflection from Inclusion Caravan." http://www.globi-observatory.org/teacher-training-in-incl usive-education-a-reflection-from-inclusion-caravan/. (accessed May 21, 2020).

[10] DepEd Order No. 008, s. 2015. "Policy Guidelines on Classroom Assessment for the K to 12 Basic Education Program." Pasig City, Philippines: Department of Education.

[11] Division Memorandum No. 524, s. 2017. "In-Service Training for Teachers (INSET) and Mid-Year Assessment." Tagbilaran City, Philippines: DepED-Division of Bohol, pp. 1-2.

[12] Division Memorandum No. 234, s. 2017. "Conduct of In-service Training for Teachers and Instructional Materials (IM) Preparation.":Dagupan City, Philippines: DepEd-Division of Dagupan.

[13] Montebon, D. R. "K12 Science Program in the Philippines: student perceptions on its implementation." International Journal of Education and Research, vol. 2, no. 12, pp. 153-164, 2014.

[14] Craddock, A. "Philippine's K12 reforms poised to transform the High Education System." https://wenr.wes.org/2016/06/philippines-k-12-reforms-p oised-transform-higher-education-student-mobility. (accessed May 17, 2020).

[15] Gatdula, S. L., Gayeta, N. E. "Garden-based strategy in teaching senior high school Life Science." Asia Pacific Journal of Multidisciplinary Research, vol. 7, no. 3, pp. 6-14, 2019.

[16] Du, E. C. "K12 Education, and the Philippines Development."Progesio Journal on Human Development, vol. 6 , no. 1, 2012.

[17] Oyteza, K. C. O. "Enhanced K to 12 Basic Education Program: Opportunities and Challenges." Economic Issue of the Day, vol. XII, no. 2, 2012.

[18] Abulencia, A. S. "The Unraveling of the K-12 Program as an Education Reforms in the Philippines." South-East Asian Journal for Youth, Sports, and Health Education, vol. 1, no. 2, pp. 229-238, 2015.

[19] Calderon, M. T. F. "A critique of the K12 Philippine Education System." International Journal of Education and Research, vol. 2, no. 10, pp. 541-551, 2014.

[20] Haron, H. "Education in the era of IR 4.0." Paper presented at the International Conference on Information Management and Technology (ICIMTech), Indonesia, 2018.

[21] Alaloul, W. S., Liew, M. S., Zawawi, N. A. W. A., Mohammed, B. S. "Industry Revolution IR 4.0: future opportunities and challenges in the construction industry." Paper Presented at the MATEC Web of Conference 203: 02010, 2018. https://doi.org/10.1051/matecconf/201820202010.

[22] Keser, H., Semerci, A. "Technology trends, Education 4.0 
and beyond."Contemporary Educational Researches Journal, vol. 9, no. 3, pp. 39-49, 2019. https://doi.org/10.18844/cerj.v9i3.4269.

[23] Foradian Technologies. "How Education 4.0 transform the school's stakeholders' experiences?" Retrieved from https://fedena.com/blog/2018/10/how-education-4-0-can-t ransform-the-schools-stakeholders-experience.html. (accessed May 30, 2020).

[24] Wallner, T., Wagner, G. “Academic Education 4.0.” Paper Presented at the International Conference on Education and New Development, pp. 155-159, 2016.

[25] Heale, R., and Twycross, A."What is a Case Study?"Evidence-Based Nursing, vol. 2, no. 1, pp. 7-8, 2018.http://dx.doi.org/10.1136/eb-2017.102845.

[26] Barbu, B. "Advertising, Microtargetting, and Social Media." Procedia - Social and Behavioral Sciences, vol. 163, pp. 44-49, 2014. DOI:10.1016/j.sbspro.2014.12.284.

[27] Kvale, S. "Interview: An Introduction to Qualitative Research Interviewing.” Sage Publications, 1996.

[28] McNamara, C. "General Guidelines for Conducting the Interview.” Minnesota, USA, 1999.

[29] Goden, L. T.,Lumbob, N. T., Niez, R. A., Coton, V. G. "Influence of Schoolheads' Instructional Competencies on Teachers' Management in Leyte Division, Philippines." International Journal of Engineering Science and Research Technology, vol. 5, no. 7, pp. 513-531, 2016. DOI: 10.5281/zenodo.57029.

[30] Roberto, J., Madrigal, D. V. "Teacher quality in the light of the Philippine Professional Standards for teachers." Philippine Social Science Journal, vol. 1, no. 1, pp. 67-79, 2018.

[31] DepEd. Order No. 32, s. 2017. “Gender-Responsive Basic Education Policy.” Pasig City, Philippines: Department of Education.

[32] DepEd. No. 35, s.2016. "The Learning Action Cell as a K to 12 Basic Education Program School-Based Continuing Professional Development for Teaching and Learning." Pasig City, Philippines” Department of Education.

[33] Hernano-Malipot, M. "DepED, WIPO to Work together to Integrate Intellectual Property in Basic Education.'https://news.mb.com.ph/2019/03/07/deped-wi po-to-work-together-to-integrate-intellectual-property-inbasic-education/. (accessed May 23, 2020).

[34] Naseem, Z., Khalid, R. "Positive Thinking in Coping Stress and Health Outcomes: A Literature Review." Journal of Research and Reflections in Education, vol. 14, no. 1, pp.
46-61, 2014

[35] Nunez, S. "Results-based Performance Management System (RPMS) for DepEd." https://prezi.com/ctktb6lpt-yu/results-based-performancemanagement-system-rpms-for-deped/. (accessed June 1, 2020).

[36] Soliven P. S. "The Teacher's Code of Ethics and moral responsibility."

https://www.philstar.com/other-section/education-and-hom e/2017/05/31/1705498/teachers-code-ethics-and-moral-res ponsibility. (accessed June 3, 2020).

[37] Voloshina, L. N., Arseenko, E. A., Panasenko, K. E., Stubunova, K. K., Tretyakov, A. A. "Impact of Self-regulation Methods on the Pyscho-Emotional State of Future Teachers." Universal Journal of Educational Research, vol. 7, no. 10B, pp. 32-37, 2019. DOI:10.13189/ujer.2019.071807.

[38] Orbe, J. R., Espinosa, A., Datukan, J. T. "Teaching Chemistry in a Spiral Progression Approach: Lessons from Science Teachers in the Philippines." Australian Journal of Teacher Education, vol. 43, no. 3, pp. 17-30, 2018.

[39] Bhowmik, M., Banerjee, B., Banerjee, J. "Role of Pedagogy Ineffective Teaching." Basic Research Journal of Education and Review, vol. 2, no. 1, pp. 1-5, 2013.

[40] Azman, M. N. A., Balakrishnan, B., Sharif, A., Baharom, S. "Retooling Science Teaching on Stability Topic for STEM Education." Malaysian Case Study. Journal of Engineering, Science and Technology, vol. 13, no. 10, pp. 3116-3128, 2018.

[41] Regional Memorandum No. 108, s. 2018. "Pedagogical Retooling in Mathematics, Language, and Science for grades 4-6 (PRIMALS Grades 4-6)." Quezon City, Philippines: DepED- National Capital Region.

[42] Learning Science Marzano Center. "Element 6: Identifying critical content."

https://www.kyrene.org/cms/lib/AZ01001083/Centricity/D omain/42/Art\%20and\%20Science/Enhanced\%20Develop mental\%20Scales/Enhanced_Developmental_Scale_E6.pd f. (accessed May 29, 2020).

[43] Subadi, T., Budiyanto, S. M., Narimo, S., Dahroni.”Lesson Study as Teachers Training Model to Improve the Quality of Education: Case Study in Surakarta Indonesia." Universal Journal of Educational Research, vol. 7, no. 12, pp. 2551-2557, 2019. DOI:10.13189/ujer.2019.071201.

[44] Altun, T. "INSET (In-Service Education and Training) and Professional Development of Teachers: A Comparison of British and Turkish Cases. US-China Education Review A, vol. 6, pp. 846-858, 2011. 